JOANNA RAJEWSKA DE MEZER

Uniwersytet im. Adama Mickiewicza

$w$ Poznaniu

\title{
EDUKACJA I PRZYGOTOWANIE ZAWODOWE WYCHOWANKÓW ZAKŁADU POPRAWCZEGO JAKO CZYNNIK WSPOMAGAJĄCY PROCES ICH READAPTACJI SPOEECZNEJ
}

\begin{abstract}
Rajewska de Mezer Joanna, Edukacja i przygotowanie zawodowe wychowanków zakładu poprawczego jako czynnik wspomagajacy proces ich readaptacji społecznej [Education and Vocational Training of Reformatory Pupils as a Supporting Factor of the Process of Their Social Re-adaptation]. Studia Edukacyjne nr 36, 2015, Poznań 2015, pp. 347-363. Adam Mickiewicz University Press. ISBN 978-83-232-2958-2. ISSN 1233-6688. DOI: 10.14746/se.2015.36.20

Entry into the vocational role and its proper performance are the evidence of social adaptation. It puts the human being in the system of social life, makes it possible to meet basic needs, to organize life time. It also the evidence of economic, social and family status. Work affects the development of self-esteem and social usefulness of man. Therefore, it is important to obtain employment and enter the social roles of a worker by people leaving institutions with a total capacity. To obtain employment it is necessary to have the relevant skills that minors can receive during education in the reformatory. Equipping minors with professional knowledge, training for a specific profession, offering courses of improvement helps them enter professional roles and facilitates their social rehabilitation.
\end{abstract}

Key words: re-adaptation, rehabilitation, vocational education, vocational training

Przemiany ustrojowe, systemowe oraz związane z nimi zmiany gospodarcze i społeczne w Polsce, które nastąpiły w przeciągu ostatnich dwudziestu kilku lat, wpłynęły w sposób istotny na funkcjonowanie człowieka obywatela - pracownika, a przez to całego społeczeństwa. Transformacja systemowa rozumiana jako zmiana podstawowych składników systemu i eliminowanie innych, utrwalonych, niesie ze sobą szereg pozytywnych 
skutków ${ }^{1}$. Jednakże, zmiana ta powoduje również skutki niepożądane i niekorzystne. Problemy związane z dynamiką elementów i układów (podsystemów społecznych) powodują także często dysfunkcjonalność uznanych wcześniej instytucji społecznych (pojawiają się np. kryzysy polityczne, ekonomiczne, instytucji edukacyjnych). W wyniku ujawniania się napięć społecznych rodzi się natomiast nierówność w układach międzyludzkich generująca ubóstwo, niedostatek, nierówność w dostępie do dóbr kultury, edukacji, czy zatrudnienia ${ }^{2}$.

Wspomniane powyżej przemiany spowodowały redefiniowanie pojęcia pracy, a sukces zawodowy nabył nowego znaczenia. Zmieniło się także podejście jednostki i społeczeństwa do podejmowania aktywności zawodowej. Posiadanie pracy zaczęło być swego rodzaju przywilejem, nie zaś prawem, a jego uzyskanie uzależnione zostało od posiadania właściwych kwalifikacji.

Opisywane zmiany (należące do niepożądanych, wspomnianych wyżej skutków transformacji) spowodowały eskalację zjawiska bezrobocia, obniżenie poziomu życia części społeczeństwa, z różnych przyczyn nie mogącego przystosować się do przebiegających procesów społecznych i gospodarczych. Brak umiejętności adaptacyjnych i w wielu przypadkach wtórny analfabetyzm kompetencyjny uniemożliwił licznej grupie Polaków odnalezienie swojego miejsca w nowej konkurencyjnej i wymagającej koncepcyjnego wysiłku rzeczywistości. Zaburzeniu uległo poczucie bezpieczeństwa egzystencji i możliwość zaspokojenia podstawowych potrzeb3. Wyzwaniem stało się zaistnienie na rynku pracy i związane $\mathrm{z}$ tym wejście $\mathrm{w}$ tak istotną obecnie rolę zawodową.

Wykonywanie pracy było, od chwili uzyskania przez człowieka świadomości swego istnienia i funkcjonowania w społeczności, jednym z najistotniejszych rodzajów jego aktywności. Umożliwiało zaspokojenie podstawowych potrzeb, pozwalało na właściwą organizację czasu, jakim dysponowała jednostka tworząca zbiorowość. Zaczęło stanowić o ekonomicznym, a zarazem i społecznym statusie jednostki, a co za tym idzie jej rodziny. Wykonywanie pracy wpływało na kształtowanie poczucia własnej wartości, przydatności społecznej człowieka.

Jednostka ludzka w trakcie swojego życia wchodzi w różne role społeczne. Współczesny człowiek należy do wielu różnych zbiorowości, w których

1 S. Kawula, Bariery resocjalizacji w świetle teorii społecznego naznaczenia, [w:] Systemowa pomoc rodzinie w procesie resocjalizacji i readaptacji społecznej, red. J. Górniewicz, H. Kędzierska, Olsztyn 2000, s. 19.

2 Tamże, s. 19-20.

3 J. Rajewska de Mezer, Rola organów pomocy społecznej wobec skutków eurosieroctwa, Studia Edukacyjne, 2011, 15, s. 107. 
zajmuje różnorodne pozycje. Rolę społeczną określamy w odniesieniu do pozycji w dwojaki sposób: jako zespół praw i obowiązków związanych z tą pozycją oraz jako schemat zachowania związanego z tą pozycją (scenariusz pozycji $)^{4}$. Przyswajanie, kanalizowanie i internalizowanie ról przypisanych jednostce, a następnie ich modyfikowanie $\mathrm{w}$ twórczym pełnieniu $\mathrm{w}$ nowych grupach społecznych stanowi istotę procesu socjalizacji ${ }^{5}$.

W okresie transformacji pojawiają się również nowe pule i wiązki nowych ról społecznych, podyktowane ścieraniem się różnych systemów wartości, opozycji, i buntów przeciwko nowym warstwom społecznym lub powstającym w wyniku zawiedzionych nadziei 6 .

Dzięki procesowi socjalizacji „(...) jednostka wdraża się do sposobu życia swojej grupy i szerszego społeczeństwa poprzez uczenie się reguł i idei zawartych w kulturze"7.

Proces socjalizacji może być rozpatrywany $\mathrm{w}$ różnych kontekstach, wśród których wymienia się kontekst: „(... 1) podmiotowy, jednostkowy, indywidualny, biograficzny, 2) kategorialny, rodzajowy, 3) grupowy, zespołowy, instytucjonalny, 4) ponadlokalny" 8 .

Socjalizacja pojmowana jest także jako proces nabywania przez człowieka cech osoby społecznej, kształtowania podmiotowych kompetencji, które tworzą możliwość funkcjonowania i zakorzenienie w strukturze danego układu społecznego, jej w nim i z nim identyfikację, a więc jej oczekiwanego i akceptowanego, uczestnictwa społecznego9.

Poprzez mechanizmy socjalizacyjne, które opierają się na kontroli społecznej, wpływie tzw. znaczących innych, czy wzmacniania wewnętrznego, jednostka „(..) uczy się podstaw relacji międzyludzkich, poznaje normy postępowania, wartości, nabywa nowe umiejętności i kształtuje swoją osobowość"10.

${ }^{4}$ B. Szacka, Wprowadzenie do socjologii, Warszawa 2003, s. 144-145.

${ }^{5}$ W. Ambrozik, Readaptacja społeczna i reorganizacja środowisk lokalnych jako warunek skuteczności oddziaływań resocjalizacyjnych, [w:] Resocjalizacja, t. 2, red. B. Urban, J.M. Stanik, Warszawa 2007, s. 183.

6 S. Kawula, Bariery resocjalizacji, s. 20.

7 P. Sztompka, Socjologia. Analiza spoteczeństwa, Kraków 2003, s. 286-287.

8 J. Modrzewski, Studia i szkice socjopedagogiczne. Aktualia, Poznań-Kalisz 2011, s. 141.

9 J. Modrzewski, Konformizm i dewiacja $w$ doświadczeniu socjalizacyjnym jednostek $i$ w ich spoŁecznej kwalifikacji, [w:] Socjalizacja dysocjacyjna w doświadczeniu indywidualnym i społecznym. Inspiracje teoretyczne i próby pedagogicznych ingerencji, red. A. Matysiak-Błaszczyk, J. Modrzewski, Poznań-Kalisz 2012, s. 24.

${ }^{10}$ C. Kurkowski, "Socjalizacja” w rodzinie z przemoca - droga ku przemocy, [w:] Pedagogika społeczna wobec problemów wspótczesnej rodziny. Polska pedagogika społeczna na początku XXI wieku, red. M. Ciczkowska-Giedziun, E. Kantowicz, Toruń 2010, s. 239. 
Niezwykle istotne w kształtowaniu człowieka, jako istoty społecznej, jest poza procesem socjalizacji także wychowanie, rozumiane jako „celowe i świadome działanie pedagogiczne zmierzające do osiągnięcia względnie stałych skutków (zmian rozwojowych) w osobowości wychowanka"11.

Dzięki socjalizacji i wychowaniu, „(...) osoby poddane temu procesowi, na skutek współdziałania także i innych czynników społecznych, kulturowych, ekologicznych, lecz i zwłaszcza podmiotowych (np. psychobiotycznych), mogą doświadczyć i internalizować rozmaite wzory biografii społecznej $(. . .)^{\prime \prime 12}$.

Dla procesu socjalizacji właściwe są wyodrębnione naukowo mechanizmy wpływające na jego przebieg: wzmacnianie, naśladownictwo, przekaz symboliczny ${ }^{13}$.

Czynniki decydujące o pomyślnym przebiegu procesu socjalizacji są różnorodne, a składają się nań znajomość treści norm społecznych, siła więzi pomiędzy socjalizującym i socjalizowanym, czynniki indywidualne (poziom sprawności intelektualnej), czynniki środowiskowe (sytuacja rodzinna więź emocjonalna rodzic-dziecko, umiejętność przekazywania dziecku informacji o obowiązujących normach społecznych i prawnych, sposób sprawowania nadzoru), sytuacja szkolna, rówieśnicza oraz wpływ czynników makrospołecznych ${ }^{14}$.

Wyróżniamy socjalizację pierwotną oraz wtórną, stanowiącą kolejny etap tego procesu.

Socjalizacją pierwotną nazywamy pierwszy, a zarazem zasadniczy etap socjalizacji, na który składa się dzieciństwo oraz wczesna młodość człowieka. W okresie tym jednostka ludzka nabywa podstawowe umiejętności, zdobywa wiedzę i informacje potrzebne jej do prawidłowego funkcjonowania w społeczeństwie. Uczy się elementarnych wzorów zachowań i podstawowych ról społecznych. W procesie socjalizacji pierwotnej następuje także kształtowanie się charakterystycznej dla danej kultury osobowości podstawowej. Socjalizacja ta przebiega $\mathrm{w}$ atmosferze nasyconej uczuciami wynikającymi z więzi emocjonalnych łączących rodziców i dziecko. Dziecko żyje w świecie zdefiniowanym przez rodziców, a świat zinternalizowany w okresie socjalizacji pierwotnej jest o wiele silniej zakorzeniony w jego świadomo-

${ }^{11}$ K. Rubacha, Edukacja jako przedmiot pedagogiki i jej subdyscyplin, [w:] Pedagogika. Podręcznik akademicki, t. 1, red. Z. Kwieciński, B. Śliwerski, Warszawa 2004, s. 26.

12 A. Matysiak-Błaszczyk, Dziewczęta w procesie socjalizacji zagrożonej dysocjacja, [w:] Socjalizacja dysocjacyjna w doświadczeniu indywidualnym $i$ społecznym.

13 B. Szacka, Wprowadzenia, s. 138.

${ }^{14}$ K. Jadach, Kurator sadowy w systemie kontroli społecznej, Studia Edukacyjne, 2009, 10, s. 238. 
ści ${ }^{15}$. Uwewnętrznienie, w tym okresie rozwoju, rzeczywistości społecznej powoduje, iż zaczyna ona kształtować najgłębsze warstwy osobowości jednostki. Początkową fazę procesu socjalizacji stanowi faza przystosowania, będąca wstępnym stadium wchodzenia jednostki w nowe grupy i role społeczne ${ }^{16}$. W fazie tej jednostka odtwarza, odwzorowuje przypisywane jej i oczekiwane przez grupę role społeczne. Dopiero w późniejszych fazach procesu socjalizacji (uspołecznienia) lub też po wnikliwym opanowaniu przez jednostkę (wyuczeniu się) przypisanych jej ról, przeciwstawia ona własną, często twórczo zmodyfikowaną koncepcję pełnienia tych ról bądź też opanowuje nowe wartości i wzory zachowań ${ }^{17}$. Do opisanych wyżej faz „kreowania ról społecznych” zaliczyć możemy socjalizację wtórną, stanowiącą drugi i zarazem ostatni etap socjalizacji jednostki, obejmujący dzieciństwo oraz okres dorosłości. Wprowadza ona człowieka w poszczególne segmenty życia społecznego i wiąże się z poznawaniem złożoności świata, a także różnych wariantów i modeli życia.

Socjalizacja wtórna jest natomiast etapem niezbędnym w procesie kształtowania zmian roli społecznej jednostki ludzkiej, natomiast jej skuteczność uwarunkowana jest możliwością odwoływania się do pewnych poznawczonormatywnych schematów, które zostały przyswojone przez jednostkę $\mathrm{w}$ okresie socjalizacji pierwotnej18. Można więc powiedzieć, że poprawny przebieg procesu socjalizacji wtórnej, stanowiącej fazę „kreowania ról społecznych" i wynikająca $\mathrm{z}$ niego umiejętność twórczego modyfikowania otrzymanego wzorca roli oraz aktywnego jej odgrywania, zależy od przebiegu procesu socjalizacji pierwotnej i jego początkowej fazy jaką jest przystosowanie.

$\mathrm{W}$ procesie socjalizacji, $\mathrm{w}$ międzypokoleniowym pasie transmisyjnym przekazywane są jednostce wzory ról społecznych, w tym roli zawodowej oraz stosunek do wykonywania danej roli.

Obecnie obserwuje się często prawidłowość polegającą na przekazywaniu międzypokoleniowym sposobu funkcjonowania społecznego, postawy wobec poszczególnych ról społecznych, w tym wspominanej już roli zawodowej.

Celem niniejszej pracy jest ukazanie nastawienia wychowanków zakładu poprawczego do pracy, wejścia $\mathrm{w}$ rolę zawodową oraz opisanie działań o charakterze edukacyjnym podejmowanych przez zakład poprawczy, ma-

${ }^{15}$ B. Szacka, Wprowadzenie, s. 152-153.

16 W. Ambrozik, Readaptacja społeczna, s. 182-183.

17 Tamże, s. 183.

${ }^{18}$ K. Olechnicki, P. Załęski, Stownik socjologiczny, Toruń 2000, s. 189-190. 
jących ułatwić readaptację społeczną wychowanka przez pomoc oferowaną mu w zdobyciu kompetencji potrzebnych do odgrywania wspomnianej roli.

Wychowankowie zakładów poprawczych stanowią specyficzną grupę społeczną. Są osobami, wobec których wykonywany jest środek poprawczy na podstawie orzeczenia sądu rodzinnego i nieletnich. Podstawą orzeczenia wymienionego wyżej środka było popełnienie czynu bądź większej liczby czynów karalnych oraz wysoki poziom demoralizacji nieletniego' ${ }^{19}$. Są oni podczas pobytu $\mathrm{w}$ zakładzie poddawani oddziaływaniom o charakterze resocjalizacyjnym. Jeżeli proces socjalizacji przebiegł nieprawidłowo, uległ na którymś z etapów zaburzeniu (nastąpiła demoralizacja jednostki, popełnienie czynu karalnego), konieczne jest poddanie jej oddziaływaniom resocjalizacyjnym celem przemiany, wymazania ze świadomości dotychczasowych treści i wprowadzenie nowych, przekształcenia dotychczasowego obrazu świata, przebudowy osobowości oraz zmiany tożsamości. W procesie tym szczególnie istotne jest naśladowanie mechanizmów socjalizacji pierwotnej ${ }^{20}$.

Według C. Czapównej i S. Jedlewskiego, którzy użyli pojęcia „resocjalizująca reedukacja", jest to proces uczenia się, w trakcie którego osoby uczące się podlegają zmianom przez eliminowanie niepożądanych nawyków o charakterze destrukcyjnym i antagonistycznym wobec oczekiwań społecznych ${ }^{21}$. Działania powyższe mogą obejmować osoby po odbyciu kary, ale i w okresie wykolejenia.

Odmienność resocjalizacji polega na tym, że poddawany jest jej człowiek $\mathrm{w}$ pewnym sensie zsocjalizowany, ale u którego wykształciły się postawy antagonistyczno-destrukcyjne $\mathrm{w}$ stosunku do społeczeństwa i ustalonych przez nie norm. Jest oddziaływaniem na „osoby źle przystosowane do środowiska społecznego, w celu umożliwienia im powrotu do normalnego życia" 22. O. Lipkowski uważa, że resocjalizacja będąca działaniem pedagogicznym zmierza do pełnego rozwoju pozytywnych cech psychofizycznych jednostki i jak najszybszego przysposobienia go do spełniania zadań społecznych, przy jednoczesnym osiąganiu zadowolenia osobistego z realizacji zadań życiowych ${ }^{23}$.

${ }^{19}$ W myśl art. 10 Ustawy z 26 października 1982 r. o postępowaniu w sprawach nieletnich (DzU 2014, poz. 382 ze zm.) - sąd rodzinny może orzec umieszczenie nieletniego w zakładzie poprawczym jeżeli nieletni dopuścił się określonego przepisami czynu karalnego, ponadto przemawia za tym wysoki stopień jego demoralizacji oraz okoliczności i charakter czynu, a inne środki wychowawcze okazały się nieskuteczne lub nie rokują resocjalizacji nieletniego.

${ }^{20}$ B. Szacka, Wprowadzenia, s. 154.

${ }^{21}$ H. Machel, Wprowadzenie do pedagogiki penitencjarnej, Gdańsk 1994, s. 14.

22 W. Okoń, Stownik pedagogiczny, Warszawa 1984, s. 258.

${ }^{23}$ O. Lipkowski, Dziecko społecznie niedostosowane i jego resocjalizacja, Warszawa 1971, s. 8. 
Resocjalizacja ma więc na celu działanie wychowawcze, które zmierza do „(...) przywrócenia osób przestępczych do normalnych warunków społecznych" 24 .

Sytuacja rodzinna wychowanków zakładu poprawczego nie sprzyja często poprawnemu przebiegowi procesu socjalizacji. Nieletni pochodzą $\mathrm{w}$ większości z rodzin rozbitych, wielokrotnie rekonstruowanych. Ich wychowaniu często towarzyszyła przemoc zarówno psychiczna, jak i fizyczna. Rozstanie rodziców spowodowane rozwodem lub separacją (formalną lub faktyczną) było wynikiem głębokiego konfliktu pomiędzy małżonkami rodzicami nieletniego, któremu towarzyszyła agresja i przemoc kierowana także wobec dzieci ${ }^{25}$. Członkowie najbliższej rodziny części wychowanków popełnili czyny karalne, skutkujące orzeczeniem wobec nich kar przewidzianych regulacjami kodeksu karnego (grzywna, ograniczenie wolności, czy pozbawienie wolności). Przekazywane im wzory ról społecznych często są niewłaściwe, niepożądane. Są to rodziny ubogie, nieprzekraczające często ustawowego kryterium dochodowego ${ }^{26}$, uprawniającego do uzyskania różnych form pomocy pieniężnej przewidzianych ustawą o pomocy społecznej.

Należy podkreślić, że osoby ulegające w procesie swojej socjalizacji wzorom zachowań - które powszechnie, $\mathrm{w}$ danym układzie społecznym, uznawane są za niepożądane, dewiacyjne, niezgodne $\mathrm{z}$ wystandaryzowanymi wzorami, prezentowanymi $\mathrm{w}$ typowych sytuacjach społecznych - postrzegane są i kwalifikowane jako zagrożone socjalizacyjnie lub zagrażające wartościom leżącym u podstaw integracji całości społecznych dominujących nad innymi i podporządkowujących je sobie samym, kreując przy tym standardy uczestnictwa społecznego człowieka27.

Badając sytuację edukacyjną wychowanków w okresie przed umieszczeniem ich w zakładzie poprawczym, obserwuje się występowanie proble-

${ }^{24}$ M. Kalinowski, Resocjalizacja nieletnich $w$ państwach europejskich o pozaeuropejskich, Warszawa 2005, s. 11.

${ }^{25}$ Szerzej problem struktury rodzin wychowanków zakładów poprawczych ujęty został $\mathrm{w}$ artykule J. Rajewska de Mezer, Rola organów pomocy społecznej w przeciwdziałaniu postępowi procesu demoralizacji nieletnich i pomocy w ich reintegracji społecznej (na przykładzie wychowanków opuszczajacych zaktady poprawcze), [w:] Nowe przestrzenie dziatania w pracy socjalnej w wymiarze etyczno-prakseologicznym, red. M. Czechowska-Bieluga, A. Kanios, L. Adamowska, Kraków 2010, s. 125.

${ }^{26}$ Kryteria dochodowe, o których mowa w tekście, to 542 zł miesięcznie na osobę samotnie gospodarującą oraz $456 \mathrm{zł}$ na osobę $\mathrm{w}$ rodzinie - zgodnie z regulacjami ustawy z 12 marca 2004 r. o pomocy społecznej (DzU z 2015, poz. 163 ze zm.).

27 J. Modrzewski, Konformizm i dewiacja $w$ doświadczeniu socjalizacyjnym jednostek $i w$ ich społecznej kwalifikacji, [w:] Socjalizacja dysocjacyjna w doświadczeniu indywidualnym $i$ społecznym. Inspiracje teoretyczne i próby pedagogicznych ingerencji, red. A. Matysiak-Błaszczyk, J. Modrzewski, Poznań-Kalisz 2012, s. 30. 
mów z nauką, skutkujących drugorocznością, kwalifikowaniem nieletnich do obniżonych wymogów programowych. Należy zauważyć, że często uczeń stwarzający problemowy edukacyjne i wychowawcze, prezentujący negatywną postawę wobec szkoły i nauki oraz niewłaściwy stosunek do nauczyciela i rówieśników, mimo ustawowego obligu objęcia go oddziaływaniami pomocowymi i korekcyjnymi, stanowi obciążenie, z którym podmioty systemu edukacji nie radzą sobie. Trzeba także podkreślić, iż negatywne doświadczenia tego okresu silnie rzutują na podejmowanie decyzji odnośnie kontynuacji edukacji w przyszłości. Genezy problemów szkolnych wychowanków zakładów poprawczych należy upatrywać w braku lub niedostatku kontroli ze strony często niewydolnych wychowawczo rodziców lub opiekunów prawnych nieletnich (dysfunkcje rodzin pochodzenia) oraz przekazywaniu wychowankowi niewłaściwych wzorów ról społecznych i strategii postępowania ${ }^{28}$.

W opisywanej grupie można dostrzec powielanie prezentowanych przez najbliższych - rodziców, opiekunów - tzw. znaczących innych, określonych postaw, także wobec roli zawodowej. Polegają one np. na braku woli podjęcia pracy przez dzieci osób bezrobotnych, unikających zatrudnienia na zasadach legalnych (na podstawie umowy o pracę lub umów cywilnoprawnych), negacji sensu pracy, bycia „wiecznym” beneficjentem instytucji wchodzących $\mathrm{w}$ skład systemu pomocy społecznej. Spotykamy się także z wyższą oceną postawy polegającej na zdobywaniu środków utrzymania bez wysiłku, także drogą nielegalną (działalność przestępcza) niż z użyciem legalnych źródeł.

Działania podejmowane $\mathrm{w}$ trakcie pobytu nieletniego $\mathrm{w}$ instytucji resocjalizacyjnej - jaką jest zakład poprawczy - zmierzają, jak wspomniano powyżej, do ponownej socjalizacji nieletniego, następującej przez eliminowanie niepożądanych nawyków o charakterze destrukcyjnym i wprowadzenia nowych treści, przekształcenia dotychczasowego obrazu świata, przebudowy osobowości.

Ich celem podstawowym jest jednak readaptacja społeczna, rozumiana jako ponowne przystosowanie się jednostki do czynnego i samodzielnego życia, wyrażającego się $\mathrm{w}$ pełnieniu ról społecznych związanych z podstawowymi sferami i płaszczyznami ludzkiej egzystencji29.

Wspominając o rolach społecznych, mamy na myśli role pełnione $\mathrm{w}$ rodzinie, rolę zawodową, czy rolę obywatelską.

28 J. Rajewska de Mezer, Edukacja zawodowa jako forma wspomagania umiejętności społecznych wychowanków zakładów poprawczych w procesie ich readaptacji spotecznej, [w:] Tożsamość osobowa dewiantów a ich reintegracja społeczna, red. A. Kieszkowska, Kraków 2011, s. 551.

${ }^{29}$ W. Ambrozik, Readaptacja społeczna, s. 182-183. 
Na przebieg procesu readaptacji społecznej wpływają nie tylko oddziaływania podejmowane $\mathrm{w}$ trakcie pobytu nieletniego $\mathrm{w}$ instytucji naprawy społecznej, choć ich znaczenie dla ponownego przystosowania społecznego jednostki jest istotne.

Na poprawny oczekiwany społecznie efekt, jakim jest readaptacja społeczna, wpływa szereg czynników oddziałujących na jednostkę poddawaną resocjalizacji na różnych etapach jej życia (preizolacyjnym, okresie przebywania w zakładzie oraz okresie postizolacyjnym) ${ }^{30}$.

Czynnikiem o istotnym znaczeniu dla wejścia w rolę zawodową (pracownika, pracodawcy, osoby prowadzącej działalność gospodarczą) jest edukacja zawodowa wychowanka.

Poza oddziaływaniami o charakterze edukacyjnym, warto także zwrócić uwagę na stosunek wychowanka do nauki zawodu oraz podejmowania działalności zawodowej, bowiem postawy pozytywne stanowią podstawę sformułowania twierdzenia o większym prawdopodobieństwie wejścia $\mathrm{w}$ przyszłości $\mathrm{w}$ rolę zawodową, a tym samym oczekiwanej readaptacji społecznej.

W celu uzyskania informacji dotyczących sytuacji edukacyjnej nieletnich podczas pobytu w zakładzie, postaw wobec edukacji zawodowej oraz wykonywania pracy, preferencji co do kierunku kształcenia zawodowego, zamierzeń związanych $\mathrm{z}$ podjęciem zatrudnienia po opuszczeniu zakładu, sytuacji zawodowej i postaw wobec pracy rodziców wychowanków, przeprowadzono badania pilotażowe w Zakładzie Poprawczym w Poznaniu.

Jest to zakład resocjalizacyjny o charakterze półotwartym, w myśl §3 pkt 1 lit. b Rozporządzenia Ministra Sprawiedliwości w sprawie zakładów poprawczych i schroniska dla nieletnich ${ }^{31}$.

Zakłady resocjalizacyjne półotwarte przeznaczone sa dla nieletnich, którzy popełnili czyny karalne, a ich niekorzystne zmiany zachowania nie dają podstaw do umieszczenia ich $\mathrm{w}$ zakładach resocjalizacyjnych otwartych ${ }^{32}$.

$\mathrm{W}$ instytucjach tych kształcenie ogólne i zawodowe oraz zatrudnianie wychowanków prowadzi się na terenie zakładu. Również zajęcia w czasie wolnym od pracy prowadzi się także na terenie zakładu lub poza zakładem, pod bezpośrednim nadzorem pracowników zakładu. W uzasadnionych przypadkach można wyrazić zgodę na kształcenie ogólne i zawodowe oraz zatrudnienie nieletnich umieszczonych $\mathrm{w}$ zakładach typu półotwartego po-

30 J. Rajewska de Mezer, Wsparcie instytucjonalne readaptacji społecznej wychowanków zakładów poprawczych, Studia Edukacyjne, 2009, 10, s. 159.

31 Rozporządzenia Ministra Sprawiedliwości z 17 października 2001 r. w sprawie zakładów poprawczych i schroniska dla nieletnich (DzU z 2014, poz. 1054).

32 §5 ust. 1 tamże. 
za zakładem. W zakładach tych liczba wychowanków w grupie wychowawczej i oddziale szkolnym nie powinna przekraczać 10 osób ${ }^{33}$.

W zakładzie poprawczym w Poznaniu wychowankowie objęci są działaniami z zakresu edukacji ogólnokształcącej oraz zawodowej. W ramach edukacji ogólnokształcącej realizują oni program szkół na następującym poziomie edukacyjnym: gimnazjum oraz zasadnicza szkoła zawodowa. Edukacja zawodowa $\mathrm{w}$ opisywanym zakładzie poprawczym odbywa się $\mathrm{w}$ zawodzie stolarza (praktyczna nauka zawodu w zasadniczej szkole zawodowej) oraz elektryka lub montera sieci instalacji i urządzeń sanitarnych (w ramach przyuczenia do zawodu podczas nauki w gimnazjum).

W celu uzyskania kwalifikacji do wykonywania zawodu, absolwenci zasadniczej szkoły zawodowej powinni w ciągu trzech lat od ukończenia szkoły zdać organizowany przez Okręgową Komisją Egzaminacyjną zawodowy egzamin teoretyczny oraz zawodowy egzamin praktyczny. W przypadku, w którym absolwent zrezygnuje z podchodzenia do wyżej wymienionych egzaminów, po ukończeniu zasadniczej szkoły zawodowej ma wykształcenie zawodowe, pozostaje jednak robotnikiem wykwalifikowanym bez zawodu. Przyuczenie do zawodu realizowane $w$ ramach gimnazjum nie daje absolwentom formalnych kwalifikacji zawodowych, jednak umożliwia zapoznanie się $\mathrm{z}$ danym zawodem, co $\mathrm{w}$ przyszłości może być pomocne przy wyborze i kontynuowaniu dalszego kształcenia zawodowego ${ }^{34}$.

Zarówno stosunek do nauki, jak i wykonywania pracy jest u poszczególnych wychowanków zróżnicowany. Rolę odgrywają w tym wypadku wcześniejsze doświadczenia okresu socjalizacji pierwotnej (m.in. obserwacja postaw związanych $\mathrm{z}$ aktywnością zawodową tzw. znaczących innych, doświadczenia szkolne).

Badania przeprowadzono metodą sondażu diagnostycznego ${ }^{35}$, z wykorzystaniem techniki ankiety oraz związanego z nią narzędzia badawczego ankiety adresowanej do wychowanków zakładu poprawczego, wobec których wykonywany jest obecnie środek poprawczy.

33 Tamże.

34 J. Rajewska de Mezer, S. Dec, Wejście w role pracownika w opiniach wychowanków zakładu poprawczego - artykuł w druku w publikacji pokonferencyjnej, wygłoszony podczas III Międzynarodowej Konferencji Naukowej „Konteksty Efektywności Profilaktyki, Resocjalizacji i Readaptacji Społecznej - Uwarunkowania efektywności wsparcia osób zagrożonych ekskluzją społeczną", Środa Wlkp., 25-26 maja 2015.

35 Metoda sondażu diagnostycznego jest metodą, która „podejmując badanie zjawisk społecznych, pozwala na badanie sądów, poglądów określonych zbiorowości, narastania zjawisk, ich tendencji i nasilenia - A. Kamiński, Metody, techniki, procedura badań w pedagogice empirycznej, [w:] Metodologia pedagogiki społecznej, red. R. Wroczyńska, T. Pilch, Wrocław 1974, s. 41. 
Grupę badawczą stanowiło 25 wychowanków Zakładu Poprawczego $\mathrm{w}$ Poznaniu, umieszczonych $\mathrm{w}$ zakładzie w celu wykonania orzeczonego wobec nich środka poprawczego.

Objęci badaniami nieletni znaleźli się $\mathrm{w}$ przedziale wiekowym między 16. a 21. rokiem życia (16 lat -1 wychowanek, 17 lat $\mathrm{w}$ trakcie badania miało - 9 nieletnich, 18 lat - 7 wychowanków, 19 lat - 2 wychowanków, 20 lat 3 wychowanków oraz 21 lat - 2 spośród badanych ${ }^{36}$ ).

Ankietowanym zadano pytanie odnośnie ich sytuacji edukacyjnej w chwili umieszczenia $\mathrm{w}$ zakładzie poprawczym. Badania wykazały, iż znaczną większość stanowili nieletni umieszczeni w placówce resocjalizacyjnej na etapie nauki w gimnazjum; było to 19 z 25 badanych, co stanowiło $76 \%$. Nieliczną grupę tworzyli natomiast wychowankowie, którzy w chwili umieszczenia $\mathrm{w}$ zakładzie poprawczym pobierali naukę $\mathrm{w}$ szkole podstawowej (4 osoby $-16 \%$ ) lub zasadniczej szkole zawodowej (1 wychowanek - 4\%). Jeden badany nie udzielił odpowiedzi na to pytanie.

Badaniami objęto także problem edukacji zawodowej wychowanków w zakładzie poprawczym (czyli tzw. wyuczonego zawodu).

Wszyscy uczestniczący w badaniach wychowankowie zostali objęci oddziaływaniami z zakresu edukacji zawodowej. Zależnie od etapu edukacyjnego, na jakim się oni znajdują, odbywają praktyczną naukę zawodu (stolarz - w przypadku zasadniczej szkoły zawodowej), przyuczają się do zawodu (elektryk bądź monter sieci instalacji i urządzeń sanitarnych - w przypadku gimnazjum) lub też doskonalą swoje kompetencje i umiejętności zawodowe $\mathrm{w}$ ramach szerokiej oferty kursowej.

Oferta proponowanych wychowankom kursów dodatkowych jest bardzo bogata i skomponowana w sposób zapewniający ogromną różnorodność. Ich głównym celem jest podwyższenie ich kompetencji zawodowych, a tym samym zwiększenie szans na znalezienie zatrudniania na obecnym rynku pracy. Nieletni biorący udział w ankiecie wymienili wśród odbytych kursów zawodowych podnoszących kompetencje zawodowe następujące: „Operator wózków jezdniowych”, „Stolarz”, „Murarz”, „Wykończenie wnętrz", „Brukarz", „Ślusarz”, ,Spawacz", „Drwal”, „Ceramika”, ,Glazurnik”, „Kucharz małej gastronomii”, „Ocieplanie budynków”, „Malarz - tapeciarz" ${ }^{37}$.

36 Zgodnie z regulacjami Ustawy z 26 października 1982 r. o postępowaniu w sprawach nieletnich (DzU z 2014, poz. 382 ze zm.) środek poprawczy może być wykonywany do ukończenia przez wychowanka 21. roku życia.

${ }^{37}$ J. Rajewska de Mezer, S. Dec, Wejście w role pracownika. 
Badanym zadano także pytania dotyczące ich preferencji zawodowych. Ma to znaczenie dla weryfikacji zgodności preferencji i realnych możliwości uzyskania przygotowania do wykonywania konkretnego zawodu.

Badani wychowankowie deklarują chęć zdobycia takich zawodów, jak: cukiernik, mechanik samochodowy, elektryk, ślusarz, budowlaniec, spawacz, stolarz, piekarz, piłkarz, pracownik ochrony. Najliczniejsza grupa deklarowała chęć zdobycia zawodu mechanika samochodowego (8 z 25, czyli 32\% badanych), następnie pracownika budowlanego (4 wychowanków - 16\%) oraz spawacza (3 wychowanków - 12\%). Trzech nieletnich zapytanych o preferencje zawodowe nie udzieliło żadnej odpowiedzi.

Badanym zadano także ważne, jeśli chodzi o ocenę chęci podnoszenia kompetencji zawodowych i związanych z nimi szans na uzyskanie zatrudnienia, pytanie o wolę kontynuowania nauki zawodu po opuszczeniu zakładu poprawczego. I w tym wypadku ankietowani podzielili się na, prawie równe ilościowo, dwie grupy: 12 z 25 (48\%) ujawniło zamiar podjęcia dalszej nauki po odbyciu środka poprawczego, natomiast 13 z 25 (52\%) nie zamierza po opuszczeniu zakładu kontynuować nauki. Jest to wynik, który może świadczyć, iż tych 12 wychowanków deklarujących wolę dalszego kształcenia pozytywnie odebrali oddziaływania o charakterze edukacyjnym prowadzone wobec nich w ramach resocjalizacji instytucjonalnej i widzą konieczność poszerzania wiedzy profesjonalnej.

Mając na uwadze przyjęty sposób definiowania pojęcia readaptacji społecznej i związane z jej poprawnym, oczekiwanym przebiegiem wejście $\mathrm{w}$ wyznaczone role społeczne ( $\mathrm{w}$ tym rolę zawodową), zadano ankietowanym pytanie dotyczące zamiaru podjęcia pracy po opuszczeniu przez nich zakładu poprawczego. Zaskakująco duża liczba wychowanków, bo aż 22 z 25 (co stanowi 88\% badanych), odpowiedziało twierdząco. Tylko 2 z 25 wychowanków $(8 \%)$ nie zamierza, a jeden wychowanek nie udzielił odpowiedzi. Uzyskany wynik świadczy o pozytywnym podejściu wychowanków do zatrudnienia, o woli podjęcia pracy, a co za tym idzie - wejścia w rolę pracownika, uzyskania niezależności finansowej.

Ankietowanym zadano także pytanie, czy będą liczyć na pomoc w znalezieniu zatrudnienia po opuszczeniu zakładu poprawczego. Bardzo pozytywne wydają się uzyskane odpowiedzi, z których wynika, że 19 z 25 badanych $(76 \%)$ udzieliło odpowiedzi twierdzącej, pięciu (20\%) wychowanków odpowiedziało przecząco, jeden wychowanek nie udzielił odpowiedzi w ogóle. Nieletni mogą liczyć na pomoc w tym zakresie, przede wszystkim ze strony rodziny i znajomych. Przy świadomości współczesnej sytuacji na rynku pracy i problemach $\mathrm{z}$ uzyskaniem zatrudnienia, pomoc $\mathrm{w}$ znalezieniu pracy uzyskana ze strony osób bliskich może mieć duże znaczenie dla po- 
prawnego przebiegu procesu readaptacji społecznej. Jest to o tyle ważne, że opuszczający zakłady poprawcze, jako osoby, które weszły w konflikt z prawem, nie cieszą się zaufaniem społecznym, a ujawnienie przez nich informacji o popełnieniu w przeszłości czynu karalnego decyduje o niechęci ich zatrudnienia przez potencjalnego pracodawcę. Mamy tu do czynienia ze skutkami stygmatyzacji, która rodzi ekskluzję społeczną i zaburza proces readaptacji społecznej wychowanka.

Z uwagi na obecną sytuację na rynku pracy w Polsce, istotny wskaźnik bezrobocia, częste przypadki utraty pracy wykonywanej $\mathrm{w}$ wyuczonym zawodzie, istnieje konieczność nabycia nowych kompetencji zawodowych przekwalifikowania zawodowego. Gotowość do podjęcia aktywności w celu zdobycia nowych umiejętności pozwalających na utrzymanie zatrudnienia świadczy o pewnej adaptabilności, elastyczności jednostki i jest pozytywnym prognostykiem readaptacji społecznej.

Zapytano więc wychowanków zakładu poprawczego o wolę przekwalifikowania zawodowego $\mathrm{w}$ razie wystąpienia takiej potrzeby. Co bardzo ciekawe, na to pytanie także większość, bo aż 21 z 25 badanych (84\%) złożyła oświadczenie o gotowości do przekwalifikowania zawodowego. Zaledwie 4 (16\%) badanych odpowiedziało odmownie. Powyższy wynik może świadczyć o ich elastyczności oraz psychicznej gotowości do przekwalifikowania zawodowego $\mathrm{w}$ razie konieczności. Stanowi to ważny pozytywny sygnał w sytuacji dużej niestabilności na obecnym rynku pracy.

Chcąc zaakcentować opisane $\mathrm{w}$ niniejszym artykule prawidłowości związane z przebiegiem procesu socjalizacji i pozostającej w związku z nim readaptacji społecznej człowieka oraz istotne dla nich mechanizmy - $w$ tym mechanizm naśladownictwa - zadano ankietowanym pytanie, które miało dać podstawę do sformułowania wniosków dotyczących przekazywania przez znaczących innych (rodziców, opiekunów prawnych) wzorów ról społecznych, a wśród nich tak istotnej roli, jak zawodowa.

Zapytano zatem, czy ojciec, ojczym bądź opiekun prawny nieletniego podejmował pracę. 24 ankietowanych $(96 \%)$ odpowiedziało na to pytanie twierdząco (w przypadku 16 osób była to praca legalna (na podstawie zawartej umowy i o charakterze stałym), w przypadku 5 osób była to tzw. "praca na czarno", czyli bez dokonania formalności związanych z ubezpieczeniem zdrowotnym i społecznym pracownika czy zleceniodawcy, natomiast w przypadku dwóch osób była to praca sezonowa, jeden wychowanek nie udzielił żadnej odpowiedzi na powyższe pytanie.

Kontynuując rozważania odnośnie sposobu funkcjonowania zawodowego ojca (ojczyma czy też opiekuna prawnego) nieletniego oraz możliwości przekazania dziecku pewnych wzorów odgrywania roli społecznej, zapyta- 
no, czy ojciec/ojczym/opiekun prawny był w trakcie swojego życia zawodowego osobą bezrobotną. Na pytanie to 11 z 25 (44\%) ankietowanych odpowiedziało twierdząco, natomiast 14 z 25 (56\%) zaprzeczyło. Wyniki odpowiedzi na to pytanie wydają się być $\mathrm{w}$ sprzeczności $\mathrm{z}$ odpowiedziami na pytanie wcześniejsze odnośnie pozostawania w zatrudnieniu ojców wychowanków, jako że na to pytanie 24 z 25 pytanych odpowiedziało wcześniej twierdząco. Można podejrzewać, że badani zinterpretowali pytanie jak sytuację, w której rodzic kiedykolwiek posiadał status bezrobotnego i pozostawał bez pracy, natomiast $\mathrm{w}$ trakcie swojego życia podejmował także zatrudnienie.

Zainteresowano się także sytuacją zawodową matki/macochy/opiekunki prawnej wychowanka. Badania wskazały, że 19 z 25 (76\%) matek nieletnich podejmowały pracę, $5 \mathrm{z}$ nich nie pracowało $(20 \%)$, jeden badany nie udzielił żadnej odpowiedzi. W przypadku 12 osób (48\%) była to praca stała (oparta na umowie o pracę lub cywilnoprawną), 9 osób (36\%) wykonywało pracę sezonową, matka jednej z osób wykonywała zarówno pracę na podstawie umowy, jak i prace "na czarno", trzech wychowanków nie udzieliło żadnej odpowiedzi.

Autorzy zapytali również, czy matki (bądź macochy, czy opiekun prawny) ankietowanych wychowanków były osobami bezrobotnymi. Na pytanie to aż 15 z 25 wychowanków (60\%) odpowiedziało twierdząco, $9(36 \%)$ zaprzeczyło, jeden nie udzielił żadnej odpowiedzi. Odpowiedzi na to i wcześniejsze (dotyczące podejmowania pracy) pytania pozwalają na sformułowanie wniosku, że rodzice nieletnich, co do zasady podejmujący aktywność zawodową przynajmniej przez pewien okres w swoim życiu byli osobami bezrobotnymi (44\% ojców/ojczymów/czy opiekunów prawnych nieletnich oraz aż 60\% matek/macoch). Co ciekawe i budujące, aż 24 z 25 (96\%) ankietowanych uznało, że wykonywanie pracy na sens. Zaledwie jedna osoba miała zdanie odmienne. Wśród pozytywów płynących z pracy wymienili oni: możliwość zdobycia niezależności - „utrzymanie się", możliwość zdobycia pieniędzy i utrzymania rodziny, a także: „możliwość nawiązania znajomości, zdobycia doświadczenia i nowych umiejętności".

Zastanawia więc, jaki wzór roli społecznej pracownika został przekazany czy wykształcony u nieletniego. Czy będzie on powielał styl pozostawania bez pracy, pracy „na czarno” - bez sformalizowania jej wykonywania, czy też, jak deklaruje $88 \%$ badanych, podejmie po opuszczeniu zakładu pracę. Na pewno wola w tym względzie ma istotne znaczenie - ukazuje postawę nieletniego wobec wykonywania pracy, świadczy o świadomości znaczenia zatrudnienia i związanego z nim wynagrodzenia. Należy jednak pamiętać, iż sama postawa i wola może nie być wystarczająca w sytuacji trudności 
związanych z realiami współczesnego rynku pracy i braku miejsc zatrudnienia. Można przypuszczać, iż na pozytywny stosunek wychowanków do świadczenia pracy i poczucie sensowności jej wykonywania istotny wpływ mają także oddziaływania instytucjonalne (podejmowane $\mathrm{w}$ zakładzie poprawczym). Są nimi: edukacja zawodowa, oferowanie ciekawej, bogatej oferty kursowej, wsparcie $\mathrm{w}$ poszukiwaniu pracy i aplikowaniu o zatrudnienie w konkretnym miejscu, ale co niemniej ważne - kształtowanie w wychowanku właściwej postawy wobec aktywności zawodowej, budowa poczucia odpowiedzialności za siebie i swoje społeczne funkcjonowanie.

Oferowane propozycje nauki zawodów: stolarza (praktyczna nauka zawodu w zasadniczej szkole zawodowej), a także elektryka lub montera sieci instalacji i urządzeń sanitarnych (przyuczenie do zawodu w ramach gimnazjum) znajdują uznanie wśród uczniów i zapewniają uzyskanie kompetencji zawodowych $\mathrm{w}$ zawodach, na które na rynku pracy jest zapotrzebowanie. Szerokie oferty kursowe pozwalają na specjalizowanie się i doskonalenie w poszczególnych kompetencjach zawodowych, co także ma zmierzać do ułatwienia zdobycia zatrudnienia przez opuszczających zakład poprawczy. Oferta kursów zawodowych organizowanych w zakładzie poprawczym jest odbierana przez wychowanków bardzo pozytywnie, bowiem traktują ją jako szybką i atrakcyjną formę podnoszenia kompetencji zawodowych ${ }^{38}$.

Wszyscy ankietowani niezwykle pozytywnie zakładają, że po opuszczeniu zakładu poprawczego zdobędą zatrudnienie; 18 (72\%) wychowanków jest zdania, że pracę zdobędą bez problemu, 7 z nich (28\%) uważa, że pracę zdobędzie, ale nie będzie to łatwe.

Podsumowując zaprezentowane powyżej wyniki badań pilotażowych odnośnie edukacji zawodowej wychowanków zakładu poprawczego i jej wpływu na proces ponownego przystosowania do funkcjonowania w społeczeństwie oraz postawy wobec aktywności zawodowej, można także wnioskować, iż oddziaływania resocjalizacyjne o charakterze edukacyjnym (kształcenie zawodowe, oferowane wychowankom kursy zawodowe podnoszące kwalifikacje zawodowe), podejmowane wobec nieletnich podczas ich pobytu $\mathrm{w}$ zakładzie poprawczym, wpływają w większości na kształtowanie ich pozytywnych postaw wobec pracy zarobkowej i zatrudnienia oraz potrzebnej do jej wykonywania edukacji. Budzą w wielu z nich poczucie sensu pracy i świadomość korzyści, jakie wynikają z jej wykonywania. Zdobywając kompetencje do działania $w$ tym zakresie, jednostka buduje poczucie własnej wartości, przyzwyczaja się do tzw. samoaktywności i znanej

38 Tamże. 
pomocy społecznej „samopomocy”. Uzyskuje tak istotne poczucie wpływu na własne życie i kierowanie nim.

Powyżej przywołane pozytywne efekty oddziaływań resocjalizacyjnych $\mathrm{w}$ tej sferze wymagają jednak wsparcia nieletniego opuszczającego instytucje naprawy społecznej przez podmioty budujące system oparcia jednostki we wczesnym etapie jej postizolacyjnej readaptacji społecznej (powiatowe centra pomocy rodzinie, ośrodki pomocy społecznej, szkoły, powiatowe urzędy pracy) oraz świadomych, chętnych do zatrudnienia wychowanków zakładów pracodawców.

Pozytywny przebieg procesu wejścia w pożądane społecznie role (czyli readaptacji społecznej) wychowanka zakładu poprawczego zależny jest bowiem od wielu współwystępujących w różnych okresach życia człowieka czynników: preizolacyjnych kompetencji osobistych nabytych $\mathrm{w}$ procesie socjalizacji, działań podjętych przez zakład w trakcie wykonywania środka poprawczego, właściwego współdziałania instytucji resocjalizującej ze znaczącymi innymi mającymi wpływ na nieletniego oraz pomocy następczej (instytucjonalnej i pozainstytucjonalnej, formalnej i nieformalnej), jaką uzyska nieletni po opuszczeniu placówki.

\section{BIBLIOGRAFIA}

Ambrozik W., Readaptacja społeczna i reorganizacja środowisk lokalnych jako warunek skuteczności oddziaływań resocjalizacyjnych, [w:] Resocjalizacja, t. 2, red. B. Urban, J.M. Stanik, Warszawa 2007.

Domachowski W., Przewodnik po psychologii społecznej, Warszawa 1998.

Jadach K., Kurator sądowy w systemie kontroli społecznej, Studia Edukacyjne, 2009, 10.

Kalinowski M., Resocjalizacja nieletnich w państwach europejskich o pozaeuropejskich, Warszawa 2005.

Kamiński A., Metody, techniki, procedura badań w pedagogice empirycznej, [w:] Metodologia pedagogiki społecznej, red. R. Wroczyńska, T. Pilch, Wrocław 1974.

Kawula S., Bariery resocjalizacji w świetle teorii społecznego naznaczenia, [w:] Systemowa pomoc rodzinie w procesie resocjalizacji i readaptacji społecznej, red. J. Górniewicz, H. Kędzierska, Olsztyn 2000.

Kurkowski C., "Socjalizacja” w rodzinie z przemoca - droga ku przemocy, [w:] Pedagogika społeczna wobec problemów wspótczesnej rodziny. Polska pedagogika społeczna na początku XXI wieku, red. M. Ciczkowska-Giedziun, E. Kantowicz, Torun 2010.

Lipkowski O., Dziecko społecznie niedostosowane i jego resocjalizacja, Warszawa 1971.

Machel H., Wprowadzenie do pedagogiki penitencjarnej, Gdańsk 1994.

Matysiak-Błaszczyk A., Dziewczęta w procesie socjalizacji zagrożonej dysocjacja, [w:] Socjalizacja dysocjacyjna w doświadczeniu indywidualnym i społecznym. Inspiracje teoretyczne i próby pedagogicznych ingerencji, red. A. Matysiak-Błaszczyk, J. Modrzewski, PoznańKalisz 2012.

Mądrzycki T., Psychologiczne mechanizmy ksztattowania się postaw, Warszawa 1970. 
Modrzewski J., Studia i szkice socjopedagogiczne. Aktualia, Poznań-Kalisz 2011.

Modrzewski J., Konformizm $i$ dewiacja $w$ doświadczeniu socjalizacyjnym jednostek $i$ w ich społecznej kwalifikacji, [w:] Socjalizacja dysocjacyjna w doświadczeniu indywidualnym i społecznym. Inspiracje teoretyczne i próby pedagogicznych ingerencji, red. A. MatysiakBłaszczyk, J. Modrzewski, Poznań-Kalisz 2012.

Okoń W., Stownik pedagogiczny, Warszawa 1984.

Olechnicki K., Załęski P., Słownik socjologiczny, Toruń 2000.

Rajewska de Mezer J., Wsparcie instytucjonalne readaptacji społecznej wychowanków zakładów poprawczych, Studia Edukacyjne, 2009, 10.

Rajewska de Mezer J., Rola organów pomocy społecznej w przeciwdziałaniu postępowi procesu demoralizacji nieletnich i pomocy w ich reintegracji społecznej (na przykładzie wychowanków opuszczajacych zakłady poprawcze), [w:] Nowe przestrzenie działania w pracy socjalnej w wymiarze etyczno-prakseologicznym, red. M. Czechowska-Bieluga, A. Kanios, L. Adamowska, Kraków 2010.

Rajewska de Mezer J., Rola organów pomocy społecznej wobec skutków eurosieroctwa, Studia Edukacyjne, 2011, 15.

Rajewska de Mezer J., Edukacja zawodowa jako forma wspomagania umiejętności społecznych wychowanków zakładów poprawczych w procesie ich readaptacji społecznej, [w:] Tożsamość osobowa dewiantów a ich reintegracja społeczna, red. A. Kieszkowska, Kraków 2011.

Rajewska de Mezer J., Dec S., Wejście w role pracownika w opiniach wychowanków zakładu poprawczego - artykuł w druku w publikacji pokonferencyjnej, wygłoszony podczas III Międzynarodowej Konferencji Naukowej „Konteksty Efektywności Profilaktyki, Resocjalizacji i Readaptacji Społecznej - Uwarunkowania efektywności wsparcia osób zagrożonych ekskluzją społeczną", Środa Wlkp., 25-26 maja 2015.

Rozporządzenia Ministra Sprawiedliwości z 17 października 2001 r. w sprawie zakładów poprawczych i schroniska dla nieletnich (DzU z 2014, poz. 1054).

Rubacha K., Edukacja jako przedmiot pedagogiki i jej subdyscyplin, [w:] Pedagogika. Podręcznik Akademicki, t. 1, red. Z. Kwieciński, B. Śliwerski, Warszawa 2004.

Szacka B., Wprowadzenie do socjologii, Warszawa 2003.

Sztompka P., Socjologia. Analiza społeczeństwa, Kraków 2003.

Ustawy z 26 października 1982 r. o postępowaniu w sprawach nieletnich (DzU z 2014, poz. 382 ze zm.).

Ustawy z 12 marca 2004 r. o pomocy społecznej (DzU z 2015, poz. 163). 